\title{
HYDRACHNA COCCINEA.
}

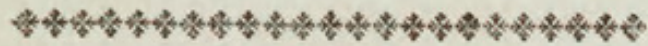 \\ CHARACTER GENERICUS。}

Caput, thorax et abdomen unita.

Palpi duo articulati.

Oculi duo, quatuor, fex.

Pedes octo.

$$
\text { Lin. Syft. Nat. Gmel. p. } 2395 .
$$

CHARACTER SPECIFICUS, Gr.

HYDRACHNA coccinea fubglobofa, fupra punctis diftantibus impreffis.

H. impreffa ? Lin. Syft. Nat. Gmel. H. rubra diftenta; punctis impreffis, palpis brevibus.

$$
\text { Müll. bydr. n. 33.t. 9. f. } 2 \text { ? }
$$

A Domino Müllero inftitutum genus Hydrachna quafi vinculo quodam connectere videtur genera araneæ et acari. Raro crefcunt hæc animalia in magnitudinem, nomine aranearum aquaticarum vulgo cognita. Minime rara hæc fpecies æftivo tempore in aquis purioribus, omnium forte quæ in Britannia generantur notatu digniffima eft. Depingitur aucta magnitudo, quæ, ut plurimum, quintam circiter unciæ partem attingit. 


400 ,

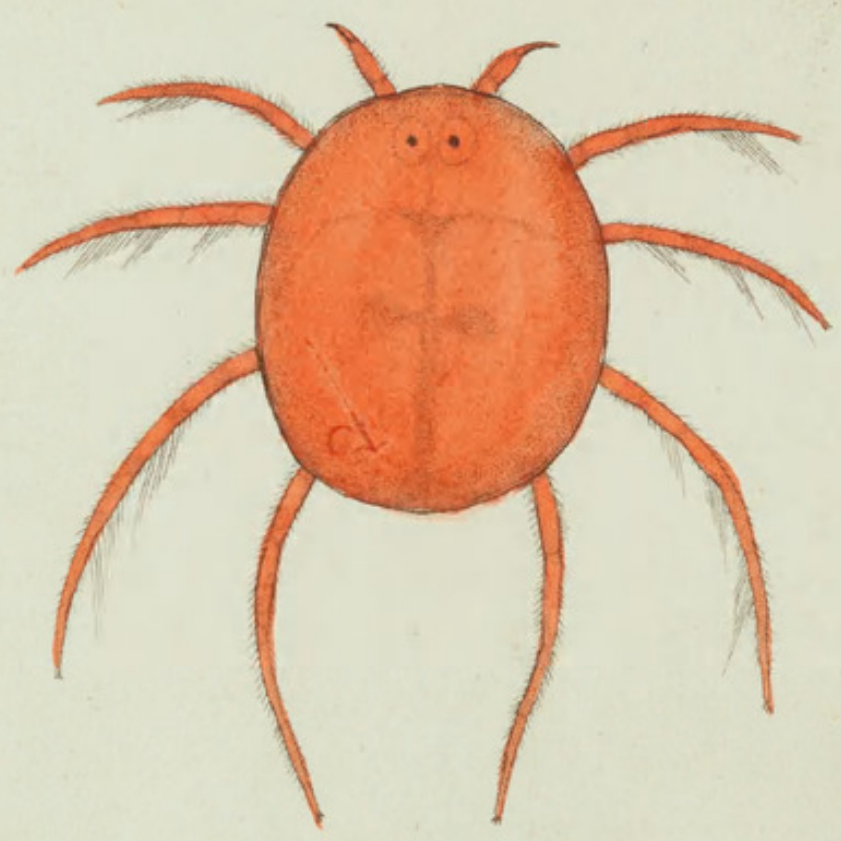

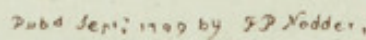




\section{SCARLET HYDRACHNA.}

Q

\section{GENERIC CHARACTER.}

Head, thorax, and abdomen united. Feelers two, jointed.

Eyes two, four, or fix.

Legs eight.

\section{SPECIFIC CHARACTER, \&ै.}

Subglobofe fcarlet HYDRACHNA, marked above with diftant impreffed points.

Scarlet HYDRACHNA, or red water-fpider.

The genus Hydrachna, inftituted by Müller, feems to form as it were a link of connexion between the genera of Acarus and Aranea. Thefe animals are commonly known by the name of water-fpiders, and are feldom of any confiderable fize. The prefent fpecies, which is fhewn as it appears when magnified, is perhaps the moft remarkable of the Britifh fpecies, and is not uncommon in clear ftagnant waters in the fummer months. It grows to the length of about the fifth part of an inch. 


\section{$2 \mathrm{BHL}$ Biodiversity Heritage Library}

Shaw, George. 1799. "Scarlet Hydrachna, Hydrachna coccinea [PI. 400]." The Naturalist's Miscellany 11(CXXI), https://doi.org/10.5962/p.310847.

View This Item Online: https://www.biodiversitylibrary.org/item/276496

DOI: https://doi.org/10.5962/p.310847

Permalink: https://www.biodiversitylibrary.org/partpdf/310847

\section{Holding Institution}

Museums Victoria

\section{Sponsored by}

Atlas of Living Australia

\section{Copyright \& Reuse}

Copyright Status: Public domain. The BHL considers that this work is no longer under copyright protection.

This document was created from content at the Biodiversity Heritage Library, the world's largest open access digital library for biodiversity literature and archives. Visit BHL at https://www.biodiversitylibrary.org. 